\title{
FACTORS AFFECTING INDIVIDUAL INVESTORS' STOCK INVESTMENT DECISION IN NEPAL
}

\author{
Surya Bahadur Rana* \\ *Lecturer, Butwal Multiple Campus, Butwal, TU
}

\begin{abstract}
This paper attempts to explore the factors associated with individual investors' stock investment decision in the context of stock market in Nepal. The study also aims to examine the relative importance of investment decision factors as perceived by investors based on their demographic characteristics. The study uses a sample responses of 106 individual investors obtained through structured questionnaire survey during the period January to April, 2019. The study employs exploratory factor analysis to extract the common factors affecting stock investment decisions of the sample investors. The results of factor analysis show that six factors, namely Earnings and Image Factors, Corporate Governance and Positioning Factors, Goodwill and Market Share Factors, Industry Competition and Size Factors, Fundamental Market Factors, and Decision Making Factors are the common factors affecting stock investment decision of the sample investors in Nepal. The results also show that among the six factors extracted, Fundamental Market Factors have high relative importance as perceived by the sample investors.
\end{abstract}

Keywords: behavioral finance - investment behavior - investment decision.

\section{INTRODUCTION}

Investors in stock market consider their investment needs, goals, objectives and constraints in making investment decisions. However, it is not possible to make a successful investment decision at all times. Conventional finance theories have two underlying assumptions about investors' decision with respect to stock market investment: first, investors make rational decisions based on their investment strategies and riskreturn consideration; second, they have neutral estimation about future stock returns. An argument against the assumptions of traditional finance theories advocates that investors do not have same nature of investment at all times, and hence their decisions also depend on their perceptions toward 
various factors that affect the investment decisions (Baghdadabad, Tanha \& Halid 2011). Similarly, Shefrin (2000), and Shleifer (2000), among others, have shown that investors' decisions largely depend on behavioral factors internal and external to them. Therefore, Warneryd (2001) rightly argues that there is a need to identify factors affecting investors' behavior that can be effective for different policymakers, issuer of securities and government to come up with additional policies and procedures needed to satisfy investors' desires and to increase market efficiency.

In behavioral finance, it is argued that investment decisions of individuals as well as the outcomes of the market are affected by both information structure in the market and the characteristics of the market participants. Thus, understanding individual investors' behavior in stock investment process has been an emerging area of study in behavioral finance. This area of study is basically concerned with identifying and understanding how investors in stock market interpret and react in response to the micro and macro information while making investment decision.

The stock market in Nepal is small but growing. The trading of shares in Nepal Stock Exchange Limited (NEPSE) started in the early 1990s with very small number of market participants. However, over the years until recent past, stock market indicators have shown that NEPSE has grown tremendously in terms of service delivery, value of transaction, volume of trade, market capitalization, and number of market participants since its establishment. Despite these growths, NEPSE started experiencing bearish trend since August 2008, which continued until the year 2010/11 and dropped to 362.85 at the end of 2010/11. However, the year 2011/12 showed a slight increase in NEPSE by 6.9 percent reaching to 389.72 points as on mid-July 2012. The NEPSE is experiencing recovery since then. In the recent period until mid-July 2019, NEPSE index is hovering around 1200 points with alternative ups and down. Thus, Nepal has witnessed alternative trends in the context of stock market growth. Besides, the investors in Nepal have also experienced complex process in transaction though the globalization of financial markets has brought wide variety of choice to the investors around the globe.

Nepalese stock market lacks sectoral diversification and has limited access to secondary trading services, insufficient transparency and efficiency of the issuer and market, limited market players, uncompetitive structure of market. Further, the market is featured by active individual 
investors and the growing but thin participation of institutional investors. The market infrastructures supporting the trading, clearing and settlement are yet to be fully developed and utilized. Thus, in between of these grounded facts of stock market in Nepal, this study attempts to identify the factors affecting stock investment decision in the context of individual investors in stock market of Nepal as perceived by them. The study also attempts to understand the relative importance of investment decision factors across different demographic character of investors so as to coincide the market mechanisms and practices consistent to the investors' behavior.

The rest of this paper is organized as follows: second section deals with literature review; third section presents conceptual framework and hypotheses of the study, fourth section deals with the methodological issues of the study; fifth section presents the study results, and finally sixth section discusses and concludes.

\section{LITERATURE REVIEW}

Understanding the determinants of investment behavior is an issue relating to behavioral finance, which argues that investors rely on different types of information for investment decision. The efficient market hypothesis has long shaped the way in which academics and practitioners analyze investment performance. The theory is based on the notion that investors act rationally and consider all available information in the decision- making process. However, Simon (1986) revealed that the investors, sometimes, do not behave rationally because of their limitations of capacity to process the information. This issue is primarily related to investors' behavior rather than the market efficiency. Thus, traditional finance theory does not incorporate the importance of investors' behavior, attitude and perception in decision making process.

A number of attempts have been made in the past to identify the types of information that investors use. Ewing (1970) carried out a study to identify those factors which motivate the investment decisions of the common stock investors. The study identified that the factors such as income from dividends, rapid growth, purposeful investment as a protective outlet of savings and professional investment management are most powerful in motivating the investment decision of the investors. The studies have identified profitability variables such as dividends, rapid growth and quick profits beside other variables such as investment for saving purposes and long-term growth as effective factors that investors use in making investment 
decisions (Potter 1971). Similarly, investors also use financial statement information for investment decisions and majority of the individual investors rely dramatically on stockbroker's consultation as main source of information about companies. The studies (such as Baker \& Haslem 1974) have basically identified the role of profitability variables such as dividends and expected returns along with firms' financial stability to influence the process of individual investors' choice. Continuing evidence revealed that corporate reports are highly considered by investors as the most important sources of information for investment decisions (Abdulla 1992).

Krishnan and Booker (2002) analyzed factors influencing the decisions of investors and found that investors basically use analysts' recommendations to arrive at a short-term decision to hold or to sell a stock. Similarly, Merikas et al. (2004) analyzed the factors influencing Greek investor behavior on the Athens Stock Exchange. The results indicated that individuals base their stock purchase decision on economic criteria combined with diverse other variables. In addition, Al-Tamimi (2006), using 343 individual investors, investigated two categories of profitability variables and past stock price (return) and identified the influencing factors on UAE investor's behavior. The influencing factors in order of importance were classified as corporate earnings, get rich quickly, stock marketability, past performance of the firm's stock, government holdings, and the creation of the organized financial markets. Maditinos, Sevic and Theriou (2007) revealed that individual investors, while making investment decision, prefer to think more about the media, newspapers and noise in market. Despite this, professional investors would rather concentrate more on technical and fundamental analysis and less on portfolio analysis. In addition, their evidence describe that all kind of investors according to accounting instruments, first look at the price earnings ratio as their first priority and consider earnings per share as their second priority, net operating profit after taxes as their third priority, and finally, return on equity as fourth priority.

In recent period, Gill et al. (2018) investigated the factors affecting investment decision making behavior through the mediation role of information searches. The study results showed positive and significant relationship between economic expectations and investment decision making behavior. But when information search was included as mediator, the relationship became insignificant and negative. Thus, the result suggested full mediation in case of economic expectations. 
The studies covering behavioral finance in the context of Nepal are very few. However, some of the studies have attempted to explore the determinants of investment decision of investors in the context of stock market in Nepal. For example, Adhikari (2010) examined the investment behavior of Nepalese investors in stock market of Nepal using the data collected from self-administered questionnaire survey. The study results revealed that Nepalese investors invested in shares for both financial and non-financial reasons. The study also observed the important role of behavioral factors in stock investment decision in the context of Nepal. Similarly, Kadariya (2012) surveyed the factors affecting investor decision making in the context of Nepalese capital market among the sample of 185 stock investors. The study revealed that capital structure and average pricing method are the most important factors that influence the investment decisions followed by factors such as political and media coverage, and financial education. The study primarily concluded that both tangible and intangible information are essential factors affecting investment decision in Nepalese capital market.

Thus, studies evidenced numerous factors affecting stock investment decision of the investors in stock market. These factors, for example, are classified as demographic factors, financial statements of companies, accounting instruments, economic variables, discounted cashflow tools, past stock price (return), consult with different resources, second-hand information resources, firms' public information, profitability variables, government policies, and past trading volume of stocks. Therefore, on the basis of cited issues, this study attempts to identify the major factors affecting stock investment decision as perceived by investors in stock market of Nepal. The study also attempts to understand the relative importance of factors with reference to demographic character that investors rely on making stock investment decision.

\section{CONCEPTUAL FRAMEWORK AND HYPOTHESES}

The relative importance of investment decision factors vary across the demographic factors such as gender, marital status, academic qualification, age group and occupation of investors. Therefore, the conceptual framework of this study incorporates an idea of examining relative importance of investment decision factors based on the demographic character of investors. Hence, the conceptual framework for the study follows the approach demonstrated in the schematic diagram in Figure 1. 


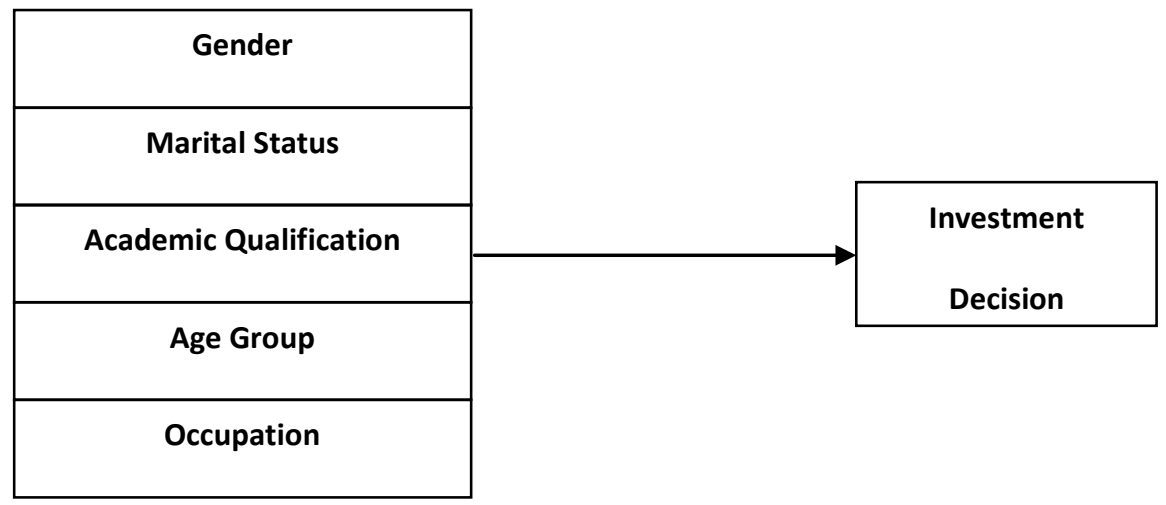

Figure 1: Conceptual framework of perception on investment decision factors

Source: Khanam (2017)

The basic framework of the study calls for identifying the differences in perception of investors about investment decision factors with respect to their gender, marital status, academic qualification, age group and occupation. Based on the given conceptual framework, this study attempts to test the following hypothesis.

H1: There is no significant difference in the relative importance of investment decision factors based on the gender of investors.

H2: There is no significant difference in the relative importance of investment decision factors based on the marital status of investors.

H3: There is no significant difference in the relative importance of investment decision factors based on the academic qualification of investors.

H4: There is no significant difference in the relative importance of investment decision factors based on the age group of investors.

H5: There is no significant difference in the relative importance of investment decision factors based on the occupation of investors.

\section{METHODOLOGY}

The details of the methodological issues associated with this study are described in the following subsections:

\section{Research design}

The nature of research design used in this study is descriptive. This design has been adopted for searching adequate information about factors 
influencing stock selection decision as perceived by the investors in stock market of Nepal. This design has also been used to assess the relative importance of investment decision factors with respect to their demographic factors such as gender, age group, academic qualification, occupation, and marital status.

\section{Nature and sources of data}

This study fully relied on primary sources of data. The structured questionnaire survey was conducted during four months from January to April, 2019 to record the opinions, perceptions, and characteristics of investors of stock market in Nepal. The survey was designed to understand the opinions of respondents as how they perceive different factors affecting their investment behavior. Besides, the study also conducted semi-structured interview with purposively selected investors who visited the broker's office during the first week of January 2019 for buying and selling of shares. The semi-structured interview was conducted to get preliminary information about the factors that investors rely on making stock investment decision.

\section{Population and sample}

Population of this study includes investors of listed firms in Nepal Stock Exchange (NEPSE) Limited to the end of April 2019. The exact numbers of stockholders of all listed companies in Nepal are unknown as there is no verified source of information to obtain this data. Therefore, in selecting the reliable and representative samples, first a detail list consisting of licensed broker firms' name and contact number was obtained from the official website of Nepal Stock Exchange Limited. There were total 50 brokerage firms licensed in NEPSE till January 2019. Second, a purposive sampling approach was used to select the sample brokerage firms where large number of individual investors is available. A total of 12 brokerage firms were identified for this purpose. At each broker's office, 20 investors were contacted with the help of authorized person at the brokers' office to complete the questionnaire. Thus, a total of 240 questionnaires were distributed for the purpose and only 168 questionnaires were returned from the respondents. On a detail verification of questionnaires received back, 62 questionnaires were found to have incomplete information and hence those could not be used for final analysis. Thus, the study was based on the complete responses from 106 respondents. 


\section{Methods of data analysis}

The primary data analyses were carried out on the basis of responses derived from structured questionnaire survey. In the first section of the questionnaire, respondents were asked to provide background information on their age, gender, occupation, marital status, and academic qualification. Second section consisted of total 28 statements about the factors affecting stock investment decision derived from literature survey and semi-structured interview conducted with investors during first week of January 2019. The 28 statements were designed in 7-points Likert Scale items, where respondents were asked to state their level of agreement and disagreement indicating 1 to 'Strongly Agree' and so on up to 7 to 'Strongly Disagree'.

The statistical tools used in this study are simple descriptive statistics such as mean and standard deviation to describe the importance of variables under consideration. Besides, the data analysis is also based on the exploratory factor analysis using principal component analysis (PCA), independent sample t-test, and one way ANOVA test. The exploratory factor analysis was conducted to explore the factors affecting stock investment decision. A reliability test for internal consistency was conducted using Cronbach's Alpha on 28 Likert items. The Cronbach's alpha also has a theoretical relation with factor analysis. As shown by Zinbarg et al. (2005), alpha may be expressed as a function of the parameters of the hierarchical factor analysis model which allows for a general factor that is common to all of the items of a measure in addition to group factors that are common to some but not all of the items of a measure.

The analysis revealed that initial Cronbach's Alpha for all 28 items was 0.879 . Although the internal consistency was good, the analysis further revealed the scope to improve the reliability by deleting some statements. In the course of improving the reliability, 5 statements were deleted. Thus, the study results are based on the 23 statements on factors affecting stock investment decision. Since the Cronbach's Alpha of remaining statements was 0.888 , the internal consistency is considered to be good. Final part of primary data analysis was based on the comparison of the observed responses across personal characteristics and across respondents' category. For this purpose, the study used independent sample t-test and one way ANOVA test to confirm the significant differences of the mean scores representing relative importance of investment decision factors across gender, marital status, occupation, academic qualification and age group of the respondents. 


\section{STUDY RESULTS}

\section{Respondents' profile}

This study is based on the responses from 106 individual investors in Nepal Stock Exchange Limited. For the purpose of this study, the respondents have been categorized based on their demographic factors which include gender, age group, marital status, occupation and academic qualification. Within gender category, 73 respondents were male and 33 female. Similarly, 38 respondents were from age group up to 30 years, 43 from age group 31 to 40 years, 21 from 41 to 50 years and 4 from above 50 years of age group. Of the 106 respondents, 84 were married and 22 were unmarried. With regard to occupation of the respondents, 38 were service holders, 31 businessman, 14 students, and 23 from other occupations. Similarly, of the 106 respondents, 64 were from undergraduate degree of academic qualification and 42 from graduate degree of qualification.

\section{Descriptive statistics}

In order to examine the relative importance of each of the 23 statements, this section deals with the results of the aggregate analysis of the factors affecting stock investment decisions of investors in Nepal.

The respondents were asked to state their level of agreement and disagreement with each of the 23 statements about factors affecting stock investment decision on 7-point Likert Scale Items. Table 1 reveals the mean score and standard deviation of the responses of investors. The results have been reported in the order of their importance to investors in stock investment decision. Lower mean score indicates higher importance of the factor. As results indicate, the most influencing top five factors are: various financial ratios of the company with mean value of 1.443 , share price to earnings ratio with mean value of 1.745 , rate of dividend paid by company with mean value of 1.840 , firms' efforts to satisfy corporate social responsibility with mean value of 1.925 , and familiarity with products and services offered by firms with mean value of 1.991 . The results also show that the factors such as competition from foreign companies, threat of new entrants in the industry, size of the company, recommendation by friends, family and peers, and stage of industry life cycle have less perceived importance in determining stock investment decisions of investors in Nepal.

\section{Reliability test}

Table 2 reveals the results of reliability test for factor analysis. Kaiser-Meyer-Olkin (KMO) measures of sampling adequacy and Bartlett's test of Sphericity have been used for this purpose. KMO measure of 


\section{FACTORS AFFECTING INDIVIDUAL INVESTORS' STOCK ...}

sampling adequacy is greater than 0.6 , which indicates that the sample size is adequate for factor analysis. The Bartlett's test of Sphericity also indicates sampling adequacy property for factor analysis as test statistic is significant at 1 percent level. This indicates that variables are significantly related to the population, and hence the data used for this study is conducive for performing factor analysis.

Table 1: Descriptive statistics

\begin{tabular}{lcc}
\hline \multicolumn{1}{c}{ Variables } & Mean & Std Dev \\
\hline Various financial ratios & 1.443 & 0.996 \\
Share price to earnings ratio & 1.745 & 0.986 \\
Rate of dividend paid & 1.840 & 1.006 \\
Corporate social responsibility & 1.925 & 1.491 \\
Familiarity with products and services & 1.991 & 1.284 \\
Return on equity & 2.009 & 1.291 \\
Quality of management & 2.132 & 1.204 \\
Major investors and institutions buying the shares & 2.179 & 1.379 \\
Satisfaction with level of dividend paid & 2.217 & 1.211 \\
Board structure and ownership composition & 2.236 & 1.239 \\
Higher institutional ownership & 2.245 & 1.504 \\
Return on assets & 2.406 & 1.504 \\
Quality of assets held & 2.406 & 1.385 \\
Expected bonus shares and right issue & 2.509 & 1.333 \\
Market share in the industry & 2.509 & 1.469 \\
Brand name popularity & 2.538 & 1.475 \\
Sensitivity of sales in industry & 2.566 & 1.317 \\
Media coverage of the shares & 2.575 & 1.591 \\
Competition from foreign companies & 2.585 & 1.567 \\
Threat of new entrants in the industry & 2.585 & 1.655 \\
Size of the company & 2.651 & 1.454 \\
Recommended by friends, family and peers & 2.755 & 1.814 \\
Stage of industry life cycle & 2.934 & 1.617 \\
\hline
\end{tabular}

Source: Author's calculation using the data from questionnaire survey.

Table 2: KMO and Bartlett's test

\begin{tabular}{l|c|c}
\hline Kaiser-Meyer-Olkin Measure of Sampling Adequacy & .779 \\
\hline Bartlett's Test of Sphericity & Approx. Chi-Square & $1.035 \mathrm{E} 3$ \\
& Degree of Freedom & 253 \\
& p-Value & .000 \\
\hline
\end{tabular}

Source: Author's calculation using the data from questionnaire survey. 


\section{Factor analysis}

The basic purpose of factor analysis in this study is to discover factors among 23 variables affecting stock investment decision of the investors in stock market of Nepal. The factors with Eigen values greater than 1 have been extracted by using Principal Component Analysis (PCA) approach and VARIMAX Rotation. Stevens (2002) reports that this rule is good if there are 10 to 30 statements and their communalities are around 0.7. The factor analysis has been conducted on 23 items in this study, and hence the number of items are appropriate to factor generated. Besides, factor analysis has been conducted using commonly used rotation method known as VARIMAX. This method maximizes the sum of the variances of the loadings, and thus final solution will have factors with loadings that are high on some variables and low on others resulting into simplified interpretation of the factors.

Table 3: Results of factor analysis for factors affecting stock investment decision

\begin{tabular}{lc}
\hline Factor 1 :Earnings and Image Factors & Factor Loading \\
\hline Rate of dividend paid & $\mathbf{0 . 7 0 9}$ \\
Quality of management & $\mathbf{0 . 7 6 8}$ \\
Return on equity & $\mathbf{0 . 7 8 0}$ \\
Return on assets & $\mathbf{0 . 6 1 6}$ \\
Quality of assets held & $\mathbf{0 . 4 6 3}$ \\
\hline Variance Explained (\%) & 29.796 \\
Eigen Value & 6.853 \\
Cronbach's Alpha & 0.796 \\
\hline Factor 2 :Corporate Governance and Positioning Factors & Factor Loading \\
\hline Corporate social responsibility & $\mathbf{0 . 7 7 8}$ \\
Board structure and ownership composition & $\mathbf{0 . 6 2 6}$ \\
Higher institutional ownership & $\mathbf{0 . 8 0 7}$ \\
Competition from foreign companies & $\mathbf{0 . 6 5 0}$ \\
\hline Variance Explained (\%) & 10.571 \\
Eigen Value & 2.431 \\
Cronbach's Alpha & 0.792 \\
\hline Factor 3: Goodwill and Market Share Factor & Factor Loading \\
\hline Media coverage of the shares & $\mathbf{0 . 8 0 6}$ \\
Brand name popularity & $\mathbf{0 . 7 3 3}$ \\
Market share of the company in the industry & $\mathbf{0 . 7 0 2}$ \\
\hline Variance Explained (\%) & 7.363 \\
Eigen Value & 1.693 \\
Cronbach's Alpha & 0.741 \\
\hline
\end{tabular}


Table 3 reports the results of factor analysis. Following Bennet et al. (2011), factor loading of minimum 0.400 has been used as threshold to determine the loading of each items to the factors generated. To identify the level of significance of factors in each group, Cronbach's Alpha has been used. As the results indicate, Cronbach's Alpha for each group is above 0.700 , and hence the items in each factor have acceptable reliability. According to Cronbach's Alpha, a total of six factors with Eigen value greater than 1 have been extracted. After careful analysis of each items loaded to the factors, they have been named as: Earnings and Image Factors (Factor 1), Corporate Governance and Positioning Factors (Factor 2), Goodwill and Market Share Factors (Factor 3), Industry Competition and Size Factors (Factor 4), Fundamental Market Factors (Factor 5), and Decision Making Factors (Factor 6).

Table 3: Continued

\begin{tabular}{lc}
\hline Factor 4:Industry Competition and Size Factors & Factor Loading \\
\hline Major investors and institutions buying the shares & $\mathbf{0 . 7 8 5}$ \\
Recommended by my friends, family and peers & $\mathbf{0 . 5 3 8}$ \\
Stage of industry life cycle & $\mathbf{0 . 5 8 9}$ \\
Threats of new entrants in industry & $\mathbf{0 . 4 8 7}$ \\
Size of the company & $\mathbf{0 . 4 8 9}$ \\
\hline Variance Explained (\%) & 6.257 \\
Eigen Value & 1.439 \\
Cronbach's Alpha & 0.755 \\
\hline Factor 5:Fundamental Market Factors & Factor Loading \\
\hline Various financial ratios & $\mathbf{0 . 8 3 5}$ \\
Share price to earnings ratio & $\mathbf{0 . 6 2 6}$ \\
Familiarity with products and services & $\mathbf{0 . 5 9 1}$ \\
\hline Variance Explained (\%) & 5.691 \\
Eigen Value & 1.309 \\
Cronbach's Alpha & 0.711 \\
\hline Factor 6: Decision Making Factors & Factor Loading \\
\hline Expected bonus and right issue & $\mathbf{0 . 6 1 8}$ \\
Satisfaction with level of dividend paid & $\mathbf{0 . 7 8 5}$ \\
Sensitivity of sales in particular industry & $\mathbf{0 . 7 4 6}$ \\
\hline Variance Explained (\%) & 4.599 \\
Eigen Value & 1.058 \\
Cronbach's Alpha & 0.709 \\
\hline
\end{tabular}

Source: Author's calculation using the data from questionnaire survey. 


\section{Relative Importance of Factors Affecting Stock Investment Decision}

This section examines the relative importance of six factors extracted from factor analysis that affect stock investment decisions of the sample investors in Nepal. Table 4 presents summated mean score and standard deviation of the six factors identified. As results indicate, the respondents generally tend to agree that these six factors have influence on their stock investment decision as summated mean score of each factor is less than 3 . However, among the six factors identified, the Fundamental Market Factors (Factor 5) have high perceived influence on stock investment decision of sample investors followed by Earnings and Image Factors (Factor 1) and then Corporate Governance and Positioning Factors (Factor 2). Among six factors, Industry Competition and Size Factors (Factor 4) have less perceived importance in affecting stock selection decision of sample investors.

Table 4: Aggregate descriptive statistics of six factors affecting stock investment decision

\begin{tabular}{lcc}
\hline \multicolumn{1}{c}{ Factors Affecting Stock Investment Decision } & Mean & Std Dev \\
\hline Factor 5: Fundamental Market Factors & 1.726 & 0.857 \\
Factor 1: Earnings and Image Factors & 2.158 & 0.957 \\
Factor 2: Corporate Governance and Positioning Factors & 2.248 & 1.142 \\
Factor 6: Decision Making Factors & 2.431 & 1.016 \\
Factor 3: Goodwill and Market Share Factors & 2.541 & 1.228 \\
Factor 4: Industry Competition and Size Factors & 2.621 & 1.131 \\
\hline
\end{tabular}

Source: Author's calculation using the data from questionnaire survey.

\section{Relative Importance of Investment Decision Factors Based on Gender}

This section examines the relative importance of six factors extracted from factor analysis across the gender category of sample investors. The analysis is based on the responses from 73 male respondents and 33 female respondents. Table 5 reports the mean and standard deviation of the responses toward six factors by male and female respondents. 
116 FACTORS AFFECTING INDIVIDUAL INVESTORS'STOCK ...

Table 5: Results of independent sample t-test with respect to gender of sample respondents

\begin{tabular}{|c|c|c|c|c|c|}
\hline & Gender & Mean & Std Dev & t-statistic & p-value \\
\hline \multirow{2}{*}{$\begin{array}{l}\text { Earnings } \\
\text { Factors }\end{array}$} & Male & 2.184 & 0.969 & \multirow{2}{*}{0.400} & \multirow{2}{*}{0.690} \\
\hline & Female & 2.103 & 0.941 & & \\
\hline \multirow{2}{*}{$\begin{array}{l}\text { Corporate Governance and } \\
\text { Positioning Factors }\end{array}$} & Male & 2.353 & 1.277 & \multirow{2}{*}{1.722} & \multirow{2}{*}{0.088} \\
\hline & Female & 2.015 & 0.729 & & \\
\hline \multirow{2}{*}{$\begin{array}{l}\text { Goodwill and } \\
\text { Share Factor }\end{array}$} & Male & 2.525 & 1.303 & \multirow{2}{*}{-0.196} & \multirow{2}{*}{0.845} \\
\hline & Female & 2.576 & 1.062 & & \\
\hline \multirow{2}{*}{$\begin{array}{l}\text { Industry Competition and } \\
\text { Size Factors }\end{array}$} & Male & 2.614 & 1.136 & \multirow{2}{*}{-0.095} & \multirow{2}{*}{0.924} \\
\hline & Female & 2.636 & 1.137 & & \\
\hline \multirow{2}{*}{$\begin{array}{l}\text { Fundamental } \\
\text { Factors }\end{array}$} & Male & 1.744 & 0.909 & \multirow{2}{*}{0.318} & \multirow{2}{*}{0.751} \\
\hline & Female & 1.687 & 0.740 & & \\
\hline \multirow{2}{*}{ Decision Making Factors } & Male & 2.434 & 0.941 & \multirow{2}{*}{0.045} & \multirow{2}{*}{0.965} \\
\hline & Female & 2.424 & 1.182 & & \\
\hline
\end{tabular}

Source: Author's calculation using the data from questionnaire survey.

As the results show, Fundamental Market Factors (Factor 5) have high perceived importance for both male and female respondents. However, the male respondents have second perceived importance to Earnings and Image Factors followed by Corporate Governance and Positioning Factors, while female respondents have second perceived importance to Corporate Governance and Positioning Factors followed by Earnings and Image Factors. For both gender categories of sample investors, Industry Competition and Size Factors have less perceived importance.

Table 5 also reports the results of independent sample t-test of mean difference across gender category. There are no significant differences in the mean scores of male of female respondents associated with Earnings and Image Factors, Goodwill and Market Share Factors, Industry Competition and Size Factors, Fundamental Market Factors, and Decision Making Factors. However, the perceived importance of Corporate Governance and Positioning Factors is significantly different between male and female investors as the result is significant at 10 percent level ( $p$-value $=0.088<0.100)$.

\section{Relative Importance of Investment Decision Factors Based on Marital Status}

Table 6 reveals the result of independent sample t-test of mean difference of the relative importance of six factors across marital status of the sample investors. 
Table 6: Results of independent sample t-test with respect to marital status of sample respondents

\begin{tabular}{|c|c|c|c|c|c|}
\hline & $\begin{array}{c}\text { Marital } \\
\text { Status }\end{array}$ & Mean & Std Dev & t-statistic & p-value \\
\hline \multirow{2}{*}{$\begin{array}{l}\text { Earnings } \\
\text { Factors }\end{array}$} & Married & 2.041 & 0.953 & \multirow{2}{*}{-2.545} & \multirow{2}{*}{0.012} \\
\hline & Unmarried & 2.609 & 0.850 & & \\
\hline \multirow{2}{*}{$\begin{array}{l}\text { Corporate Governance } \\
\text { and Positioning Factors }\end{array}$} & Married & 2.110 & 1.074 & \multirow{2}{*}{-2.481} & \multirow{2}{*}{0.015} \\
\hline & Unmarried & 2.773 & 1.263 & & \\
\hline \multirow{2}{*}{$\begin{array}{l}\text { Goodwill and } \\
\text { Share Factor }\end{array}$} & Married & 2.444 & 1.227 & \multirow{2}{*}{-1.591} & \multirow{2}{*}{0.115} \\
\hline & Unmarried & 2.909 & 1.187 & & \\
\hline \multirow{2}{*}{$\begin{array}{l}\text { Industry Competition and } \\
\text { Size Factors }\end{array}$} & Married & 2.424 & 1.027 & \multirow{2}{*}{-3.709} & \multirow{2}{*}{0.000} \\
\hline & Unmarried & 3.373 & 1.218 & & \\
\hline \multirow{2}{*}{$\begin{array}{l}\text { Fundamental } \\
\text { Factors }\end{array}$} & Married & 1.615 & 0.760 & \multirow{2}{*}{-2.691} & \multirow{2}{*}{0.008} \\
\hline & Unmarried & 2.152 & 1.073 & & \\
\hline \multirow{2}{*}{ Decision Making Factors } & Married & 2.385 & 1.025 & \multirow{2}{*}{-0.908} & \multirow{2}{*}{0.366} \\
\hline & Unmarried & 2.606 & 0.985 & & \\
\hline
\end{tabular}

Source: Author's calculation using the data from questionnaire survey.

Married respondents tend to have higher perceived importance to Fundamental Market Factors followed by Earnings and Image Factors, and then Corporate Governance and Positioning Factors, while unmarried respondents tend to have high perceived importance to Fundamental Market Factors followed by Decision Making Factors, and then earnings and Image Factors. The results of independent sample t-test show that married and unmarried investors tend to have significant difference in their perception toward the importance ofEarnings and ImageFactors ( $\mathrm{p}$-value $=0.012<0.050$ ), Corporate Governance and Positioning Factors ( $\mathrm{p}$-value $=0.015<0.050$ ), Industry Competition and Size Factors ( $\mathrm{p}$-value $=0.000<0.010$ ), and Fundamental Market Factors ( $\mathrm{p}$-value $=0.008<0.010$ ) because results are significant at 5 percent and 1 percent level respectively. However, results show that married and unmarried investors do not differ significantly in terms of their perceptions towards the effect of Goodwill and Market Share Factors and Decision Making Factors.

\section{Relative Importance of Investment Decision Factors Based on Qualification}

Table 7 reports the result of independent sample t-test of mean difference of the relative importance of six factors across academic qualification of the respondents. The analysis is based on 64 respondents from undergraduate academic degree and 42 from graduate academic degree. 
Table 7: Results of independent sample t-test with respect to academic qualification of sample respondents

\begin{tabular}{|c|c|c|c|c|c|c|}
\hline & & Qualification & Mean & Std Dev & t-statistic & p-value \\
\hline \multirow{2}{*}{$\begin{array}{l}\text { Earnings and } \\
\text { Factors }\end{array}$} & \multirow{2}{*}{ Image } & Undergraduate & 2.116 & 0.962 & \multirow{2}{*}{-0.568} & \multirow{2}{*}{0.572} \\
\hline & & Graduate & 2.224 & 0.957 & & \\
\hline \multirow{2}{*}{\multicolumn{2}{|c|}{$\begin{array}{l}\text { Corporate Governance } \\
\text { and Positioning Factors }\end{array}$}} & Undergraduate & 2.164 & 1.135 & \multirow{2}{*}{-0.930} & \multirow{2}{*}{0.355} \\
\hline & & Graduate & 2.375 & 1.155 & & \\
\hline \multirow{2}{*}{$\begin{array}{l}\text { Goodwill and } \\
\text { Share Factor }\end{array}$} & \multirow{2}{*}{ Market } & Undergraduate & 2.609 & 1.286 & \multirow{2}{*}{0.707} & \multirow{2}{*}{0.481} \\
\hline & & Graduate & 2.437 & 1.142 & & \\
\hline \multirow{2}{*}{\multicolumn{2}{|c|}{$\begin{array}{l}\text { Industry Competition } \\
\text { and Size Factors }\end{array}$}} & Undergraduate & 2.509 & 1.115 & \multirow{2}{*}{-1.255} & \multirow{2}{*}{0.221} \\
\hline & & Graduate & 2.791 & 1.148 & & \\
\hline \multirow{2}{*}{$\begin{array}{l}\text { Fundamental } \\
\text { Factors }\end{array}$} & \multirow{2}{*}{ Market } & Undergraduate & 1.688 & 0.858 & \multirow{2}{*}{-0.575} & \multirow{2}{*}{0.566} \\
\hline & & Graduate & 1.786 & 0.861 & & \\
\hline \multirow{2}{*}{$\begin{array}{l}\text { Decision } \\
\text { Factors }\end{array}$} & \multirow[t]{2}{*}{ Making } & Undergraduate & 2.505 & 1.189 & \multirow{2}{*}{1.037} & \multirow{2}{*}{0.302} \\
\hline & & Graduate & 2.318 & 0.671 & & \\
\hline
\end{tabular}

Source: Author's calculation using the data from questionnaire survey.

As the results indicate, Fundamental Market Factors have high perceived importance to the undergraduate respondents in making stock investment decision and so is the case for graduate respondents. Similarly, both types of respondents give second most importance to Earnings and Image Factors followed by Corporate Governance and Positioning Factors by undergraduate and Decision Making Factors by graduate respondents. Table 7 also shows the results of independent sample t-test of mean difference between undergraduate and graduate respondents. These two types of respondents do not tend to have significant difference in the relative importance of six factors because mean differences are all insignificant at 10 percent level ( $\mathrm{p}$-values $>0.100)$.

\section{Relative Importance of Investment Decision Factors Based on Age Group}

The results of one way ANOVA with respect to age group of sample investors and factors affecting stock investment decisions are provided in Table 8. For the purpose of analysis, respondents are categorized into four age groups as indicated in the table. The relative importance of Earnings and Image Factors and Goodwill and Market Share Factors are not significantly different among four age groups of sample investors. However, they differ significantly with respect to their perceived importance to Corporate Governance and Positioning Factors, Industry Competition and Size Factors, Fundamental Market Factors and Decision Making Factors. The respondents from all age group, except those of age above 50 years, tend 
to give high perceived importance to Fundamental Market Factors, while respondents above the age of 50 tend to give more importance to Earning and Image Factors.

Table 8: One way ANOVA with respect to age group of sample investors

\begin{tabular}{|c|c|c|c|c|c|c|}
\hline \multicolumn{2}{|c|}{ Variables } & $\begin{array}{c}\text { Age } \\
\text { group }\end{array}$ & Mean & Std dev & F-Statistic & p-value \\
\hline \multirow{4}{*}{\multicolumn{2}{|c|}{$\begin{array}{l}\text { Earnings and Image } \\
\text { Factors }\end{array}$}} & $20-30$ & 2.353 & 0.967 & \multirow{4}{*}{1.941} & \multirow{4}{*}{0.128} \\
\hline & & $31-40$ & 2.163 & 0.857 & & \\
\hline & & $41-50$ & 1.962 & 1.129 & & \\
\hline & & Above 50 & 1.300 & 0.115 & & \\
\hline \multirow{4}{*}{\multicolumn{2}{|c|}{$\begin{array}{l}\text { Corporate Governance } \\
\text { and Positioning Factors }\end{array}$}} & $20-30$ & 2.553 & 1.050 & \multirow{4}{*}{2.289} & \multirow{4}{*}{0.083} \\
\hline & & $31-40$ & 2.238 & 1.180 & & \\
\hline & & $41-50$ & 1.774 & 0.961 & & \\
\hline & & Above 50 & 1.983 & 1.875 & & \\
\hline \multirow{4}{*}{\multicolumn{2}{|c|}{$\begin{array}{l}\text { Goodwill and Market } \\
\text { Share Factors }\end{array}$}} & $20-30$ & 2.675 & 1.116 & \multirow{4}{*}{0.857} & \multirow{4}{*}{0.466} \\
\hline & & $31-40$ & 2.574 & 1.294 & & \\
\hline & & $41-50$ & 2.175 & 1.241 & & \\
\hline & & Above 50 & 2.833 & 1.551 & & \\
\hline \multirow{4}{*}{\multicolumn{2}{|c|}{$\begin{array}{l}\text { Industry Competition } \\
\text { and Size Factors }\end{array}$}} & $20-30$ & 3.132 & 1.365 & \multirow{4}{*}{4.938} & \multirow{4}{*}{0.003} \\
\hline & & $31-40$ & 2.433 & 0.847 & & \\
\hline & & $41-50$ & 2.229 & 0.945 & & \\
\hline & & Above 50 & 1.850 & 0.379 & & \\
\hline \multirow{4}{*}{$\begin{array}{l}\text { Fundamental } \\
\text { Factors }\end{array}$} & \multirow{4}{*}{ Market } & $20-30$ & 2.009 & 1.015 & \multirow{4}{*}{3.486} & \multirow{4}{*}{0.019} \\
\hline & & $31-40$ & 1.713 & 0.818 & & \\
\hline & & $41-50$ & 1.318 & 0.387 & & \\
\hline & & Above 50 & 1.332 & 0.471 & & \\
\hline \multirow{4}{*}{$\begin{array}{l}\text { Decision } \\
\text { Factors }\end{array}$} & & $20-30$ & 2.614 & 1.075 & \multirow{4}{*}{3.025} & \multirow{4}{*}{0.033} \\
\hline & Making & $31-40$ & 2.287 & 0.875 & & \\
\hline & & $41-50$ & 2.175 & 1.036 & & \\
\hline & & Above 50 & 3.583 & 1.032 & & \\
\hline
\end{tabular}

Source: Author's calculation using the data from questionnaire survey.

\section{Relative Importance of Investment Decision Factors Based on Occupation}

The results of one way ANOVA with respect to age group of sample investors and factors affecting stock investment decisions are provided in Table 9. Respondents were categorized into four occupation group, namely service holders, businessman, students a, and others. The respondents tend to have 
no significant difference in their perceptions towards the role of Earnings and Image Factors, Goodwill and Market Share Factors, Industry Competition and Size Factors and Decision Making Factors as factors affecting stock investment decision. However, they tend to have different perceptions regarding the role of Corporate Governance and Positioning Factors and Fundamental Market Factors. The results also indicate that Fundamental Market Factors have high perceived importance as factors affecting stock investment decisions for respondents from all occupational categories.

Table 9: One way ANOVA with respect to Occupation of Sample Investors

\begin{tabular}{|c|c|c|c|c|c|}
\hline Variables & Occupation & Mean & Std Dev & F-Statistic & p-value \\
\hline \multirow{4}{*}{$\begin{array}{l}\text { Earnings and Image } \\
\text { Factors }\end{array}$} & Service & 2.284 & 1.062 & \multirow{4}{*}{2.133} & \multirow{4}{*}{0.101} \\
\hline & Business & 1.800 & 0.568 & & \\
\hline & Student & 2.314 & 0.858 & & \\
\hline & Other & 2.340 & 1.157 & & \\
\hline \multirow{4}{*}{$\begin{array}{l}\text { Corporate } \\
\text { Governance and } \\
\text { Positioning Factors }\end{array}$} & Service & 2.566 & 1.304 & \multirow{4}{*}{2.732} & \multirow{4}{*}{0.048} \\
\hline & Business & 1.807 & 0.935 & & \\
\hline & Student & 2.393 & 0.918 & & \\
\hline & Other & 2.228 & 1.100 & & \\
\hline \multirow{4}{*}{$\begin{array}{l}\text { Goodwill and Market } \\
\text { Share Factor }\end{array}$} & Service & 2.614 & 1.234 & \multirow{4}{*}{0.121} & \multirow{4}{*}{0.947} \\
\hline & Business & 2.441 & 1.323 & & \\
\hline & Student & 2.595 & 1.403 & & \\
\hline & Other & 2.522 & 1.029 & & \\
\hline \multirow{4}{*}{$\begin{array}{l}\text { Industry Competition } \\
\text { and Size Factors }\end{array}$} & Service & 2.842 & 1.200 & \multirow{4}{*}{2.041} & \multirow{4}{*}{0.113} \\
\hline & Business & 2.245 & 0.973 & & \\
\hline & Student & 2.929 & 1.295 & & \\
\hline & Other & 2.574 & 1.029 & & \\
\hline \multirow{4}{*}{$\begin{array}{l}\text { Fundamental Market } \\
\text { Factors }\end{array}$} & Service & 1.965 & 0.958 & \multirow{4}{*}{3.417} & \multirow{4}{*}{0.020} \\
\hline & Business & 1.495 & 0.774 & & \\
\hline & Student & 2.048 & 0.986 & & \\
\hline & Other & 1.449 & 0.499 & & \\
\hline \multirow{4}{*}{$\begin{array}{l}\text { Decision Making } \\
\text { Factors }\end{array}$} & Service & 2.298 & 0.701 & \multirow{4}{*}{0.646} & \multirow{4}{*}{0.587} \\
\hline & Business & 2.462 & 1.042 & & \\
\hline & Student & 2.738 & 1.235 & & \\
\hline & Other & 2.420 & 1.276 & & \\
\hline
\end{tabular}

Source: Author's calculation using the data from questionnaire survey. 


\section{DISCUSSION AND CONCLUSION}

This paper attempted to identify the factors associated with investment decision of investors in stock market of Nepal and also explored the relative importance of investment decision factors across the demographic characteristics of individual investors. The study was based on sample responses of 106 individual investors obtained through structured questionnaire survey during the period January to April, 2019. The study employed exploratory factor analysis to extract the common factors affecting stock investment decisions of the sample investors in Nepal. The results of factor analysis demonstrated Earnings and Image Factors, Corporate Governance and Positioning Factors, Goodwill and Market Share Factors, Industry Competition and Size Factors, Fundamental Market Factors, and Decision Making Factors as the common factors affecting stock investment decision of the sample investors in Nepal. The results also showed that among the six factors extracted, Fundamental Market Factors have high relative importance as perceived by the sample investors followed by Earnings and Image Factors, and Corporate Governance and Positioning Factors. Fundamental Market Factors were observed significant factor in investment decision making process across all analysis in aggregate as well as across different demographic characteristics of investors. This result documented in the study has a practical implication in the context of Nepalese stock market. First, the consideration of fundamental market factors is associated with the level of investment education and awareness on the part of investors (Syawiyanti \& Kuswanto 2019). Therefore, individual investors in Nepal can be regarded to have marched to look into the fundamental market factors primarily due to the increased level of investment education and awareness. Investors' concern to the Earnings and Image Factors and Corporate Governance and Positioning Factors documented in this study implies that Nepalese investors' concern toward firm specific fundamentals and board practices are also increasing, and hence they started giving due priority to these factors in investment decision making.

Despite of the sincere efforts made for arriving at meaningful conclusions from the study, some limitations deserve consideration in order to obtain reliable interpretation of the results. First, all respondents 
are from Kathmandu valley since brokers' offices are mostly concentrated in Kathmandu valley, and hence, the study does not incorporate wide geographical character of the respondents. Hence, there exists future scope to incorporate the respondents from wide geographical location in this type of study. Another limitation of this study is related to the sample size. Thus, further attempts are required with larger sample sizes to make inferences or generalizations. Finally, the study has attempted only to explore the factors associated with investment decisions and their relative importance with respect to the demographic character of investors. So, there exists a scope for future study to incorporate the causal comparative study design to analyze the effect size of investment decision variables on investment behavior of individual investors in stock market of Nepal.

\section{REFERENCES}

Abdulla, J.Y.A. (1992). Disclosure needs of major users of corporate reports in Bahrain. Journal of Economics and Administrative Science, 8: 135-167.

Adhikari, P. (2010). Investment behavior of Nepalese investors. PYC Nepal Journal of Management, 3(1): 47-58.

Al-Tamimi, H. (2006). Factors influencing individual investor behavior: An empirical study of the UAE financial markets. Journal of Business Review, 5(2): 225- 232.

Baghdadabad, M.R.T., Tanha, F.H. \& Halid, N. (2011). A study on small investors' behavior in choosing stock: Case study: Kuala-Lumpur stock market. African Journal of Business Management, 5(27): 11082-11092.

Baker, H.K. \& Haslem, J.A. (1974). Toward the development of clientspecified valuation models. Journal of Finance, 29(4): 1255-1263.

Ewing, P.R. (1970). Motivating factors guiding the common stock investor. Dissertation Abstracts International, 31(5): 1970-1975.

Gill, S., Khurshid, M. K., Mahmood, S. \& Ali, A. (2018). Factors effecting investment decision making behavior: The mediating role of information searches. European Online Journal of Natural and Social Sciences, 7(4): 758-767. 
Kadariya, S. (2012). Factors affecting investor decision making: A case of Nepalese capital market. Journal of Research in Economics and International Finance, 1(1): 16-30.

Khanam, Z. (2017). The impact of demographic factors on the decisions of investors during dividend declaration: A study on Dhaka Stock Exchange, Bangladesh. IOSR Journal of Business and Management, 19(8): 01-07.

Krishnan, R. \& Booker, D. M. (2002). Investors' use of analysts' recommendations. Behavior Research in Accounting, 14:129-158.

Maditinos, D., Sevic, Z. \& Theriou, N. (2007). Investors' behavior in the Athens Stock Exchange. Studies in Economics and Finance, 24(1): 32-50.

Merikas, A. A., Merikas, A. G., Vozikis, G. S. \& Prasad, D. (2004). Economic factors and individual investor behavior: The case of the Greek Stock Exchange. Journal of Applied Business Research, 20(4): 35-44.

Potter, R.E. (1971). An empirical study of motivations of common stock investors. Southern Journal of Business, 6(1): 41-44.

Shefrin, H. (2000). Beyond greed and fear. Boston: Harvard Business School Press.

Shleifer, A. (2000). Inefficient markets: An introduction to behavioral finance. Oxford: Oxford University Press.

Simon, H. A. (1986). Rationality in psychology and economics. Journal of Business, 59: 209-224.

Stevens, J. P. (2002). Applied multivariate statistics for the social sciences. Hillsdale, NS: Erlbaum.

Syawiyanti, A. R. \& Kuwanti, A. (2019). An analysis of factors influencing investment decision making in Indonesia's capital market. International Journal of Economics, Commerce and Management, 7(5): 58-69. 
124 FACTORS AFFECTING INDIVIDUAL INVESTORS' STOCK ...

Warneryd, K.E. (2001). Stock-market psychology: How people value and trade stocks. Cheltenham: Edward Elgar.

Zinbarg, R., Yovel, I., Revelle, W. \& McDonald, R. (2006). Estimating generalizability to a universe of indicators that all have an attribute in common: A comparison of estimators. Applied Psychological Measurement, 30: 121-144. 